\title{
Asupan yodium dan asupan goitrogenik hubungannya dengan status gangguan akibat kekurangan yodium (GAKY) pada anak sekolah dasar di Kabupaten Dairi Provinsi Sumatra Utara
}

\author{
Urbanus Sihotang ${ }^{1}$, Toto Sudargo ${ }^{2}$, Dhuto Widagdo ${ }^{3}$
}

\begin{abstract}
Background: lodine deficiency disorder (IDD) is a health problem which affects the quality of human resources. IDD is caused by lack of iodine substance. The substance is needed for numerous syntheses and metabolism in the body, particularly thyroid glands. IDD may also be caused by high consumption goitrogenic substance.

Objective: The study was meant to identify relationship between iodine and thiocyanate intake and IDD, and to identify differences in iodine and thiocyanate intake based on endemic level.

Method: This was an observational study with cross sectional design. Method used were palpation of goiter glands to measure endemic level, food recall, and food frequency questionnaire (FFQ) to measure iodine and thiocyanate intake, ammonium persulfate digestion to measure urine iodine excretion. Data analysis used chi-square, Pearson correlation and anova.

Results: The result of chi-square analysis showed that there was no significant relationship between iodine intake and IDD ( $p>0.05, \mathrm{Cl} 95 \%$ : 0,34-1,18), but there was significant relationship between iodine intake and urine iodine excretion ( $p<0.05, \mathrm{Cl} 95 \%$ : 2.2-7.2) with OR 3.9. There was significant relationship between IDD and thiocyanate intake ( $p<0.05, \mathrm{Cl} 95 \%$ : 3.0-11.3) with OR 5.9, but there was no significant relationship between thiocyanate intake and urine iodine excretion ( $p>0.05, \mathrm{Cl} 95 \%$ : 0.48-1.97). The result of Pearson correlation test showed that there was no significant relationship between iodine and thiocyanate $F F Q$ and IDD $(p>0.05)$; there was no significant relationship (but there was a tendency) between thiocyanate FFQ and IDD $(p>0.05)$. There were significant differences in iodine intake, thiocyanate intake, iodine FFQ and thiocyanate FFQ based on endemic level ( $p>0.05$ ).

Conclusion: There was relationship between iodine intake and IDD/non-IDD, but there was relationship between urine iodine excretion and IDD. Children with IDD had higher consumption of thiocyanate than those who did not have IDD. There were differences in all measurements based on endemic level.
\end{abstract}

KEY WORDS iodine deficiency disorder, iodine intake, thiocyanate intake, urine iodine excretion, food frequency questionnaire

\section{PENDAHULUAN}

Gangguan akibat kekurangan yodium (GAKY) merupakan salah satu dari empat masalah gizi utama di Indonesia dan termasuk masalah kesehatan masyarakat yang serius mengingat dampaknya yang mempengaruhi kelangsungan hidup dan kualitas sumber daya manusia (1). Pada penderita GAKY timbul sekumpulan gejala klinis karena tubuh kekurangan yodium. Jika asupan yodium kurang dari yang dibutuhkan, fungsi kelenjar tiroid akan terganggu dan memicu sekresi thyroid stimulating hormon (TSH) yang merangsang kelenjar tiroid untuk menyerap lebih banyak yodium. Hal ini menyebabkan kelenjar tiroid bekerja lebih giat, sehingga secara perlahan kelenjar ini membesar (hiperplasi) dan disebut gondok (2).

Kekurangan yodium yang terjadi pada masa kehamilan dapat menyebabkan abortus, lahir mati, cacat bawaan, ganguan perkembangan otak, dan melahirkan anak kretin, sedangkan bila terjadi pada anak dan remaja dapat menyebabkan gondok, hipotiroidisme, gangguan fungsi mental, rendahnya prestasi belajar, pertumbuhan terhambat, dan pada orang dewasa mengakibatkan rendahnya produktivitas kerja (2).

Secara umum, penyebab GAKY adalah defisiensi yodium yang berat. Meskipun demikian, berdasarkan studi epidemiologi GAKY menunjukkan bahwa menetap dan berkembangnya kasus-kasus baru di daerah gondok endemis dipengaruhi oleh faktor lingkungan, di antaranya mengkonsumsi zat-zat goitrogenik. Zat goitrogenik terdapat dalam bahan makanan yang menyebabkan penyakit gondok karena menghambat sintesis dan sekresi hormon tiroid (3), mempercepat pengeluaran iodida dari kelenjar tiroid $(4,5)$, dan utilisasi yodium tidak sempurna (6).

Penelitian di Malaysia membuktikan bahwa zat goitrogenik berhubungan erat dengan fungsi hormon tiroksin (7). Selain

\footnotetext{
Politeknik Kesehatan Departemen Kesehatan RI Medan Jurusan Gizi, Simpang Tanjung Garbus Lubuk Pakam, Kabupaten Deli Serdang, Sumatra Utara

2 Magister Gizi Kesehatan UGM, JI Farmako, Sekip Utara, Yogyakarta 55281, e-mail : totosud@indosat.net.id

3 Balai Penelitian Pengembangan GAKY, Jayan, Borobudur, Kabupaten Magelang, Jawa Tengah
} 
itu, penelitian tentang hubungan goitrogenik dengan kejadian GAKY di Sarawak, Malaysia juga membuktikan bahwa konsumsi ubi kayu berhubungan dengan kejadian gondok dan kretin (4). Tingginya prevalensi kretin di Daerah Ubangi, Zaire disebabkan oleh kekurangan yodium, selenium, dan konsumsi tiosianat (SCN) yang bersifat goitrogenik dalam jumlah berlebihan (8). Pengaruh tiosianat dalam sintesis hormon tiroksin makin besar potensinya apabila terjadi di daerah defisiensi yodium (9). Penelitian di Maluku menunjukkan bahwa asupan goitrogenik tiosianat akan memperberat endemisitas coastal goiter pada wilayah yang defisiensi yodium (10). Santoso (11) menjelaskan ada hubungan antara asupan goitrogenik tiosianat dengan ekskresi yodium urin (EYU).

Berdasarkan hasil survei GAKY tahun 2003, prevalensi TGR (total goiter rate) Kabupaten Dairi sebesar 33,9\%. Angka ini jauh di atas angka TGR Provinsi Sumatra Utara yang hanya sebesar $5,3 \%$ dan TGR nasional sebesar $11,1 \%$. Demikian juga nilai median kadar EYU Kabupaten Dairi sebesar $38,8 \%(<100 \mu \mathrm{g} / \mathrm{L})$ yang menunjukkan daerah tersebut berpotensi mengalami kekurangan yodium. Nilai tersebut jauh di atas nilai Provinsi Sumatra Utara yang sebesar $13,2 \%$ maupun nasional yang sebesar $16,3 \%$ (1). Tingginya prevalensi GAKY di Kabupaten Dairi tersebut diduga karena pola konsumsi makan sayur-sayuran. Kabupaten Dairi terletak di dataran tinggi dan jauh dari laut dengan mata pencaharian sebagian besar penduduk yaitu bertani, terutama sayur-sayuran.

Penelitian ini bertujuan untuk mengetahui hubungan antara asupan yodium dan zat goitrogenik dari bahan makanan dengan status GAKY pada anak-anak SD (sekolah dasar) di Kabupaten Dairi serta untuk mengetahui perbedaan asupan yodium dan asupan goitrogenik berdasarkan tingkat endemisitas di Kabupaten Dairi.

\section{BAHAN DAN METODE}

\section{Rancangan dan sampel penelitian}

Jenis penelitian ini adalah observasional dengan rancangan cross sectional yang dilaksanakan pada bulan November sampai dengan Desember 2006 di 4 kecamatan di Kabupaten Dairi, Provinsi Sumatra Utara. Kecamatan tersebut antara lain: Kecamatan Parbuluan, Kecamatan Silima Pungga-Pungga, Kecamatan Sidikalang, dan Kecamatan Silahi Sabungan.

Populasi penelitian meliputi semua anak SD di Kabupaten Dairi dan sampel penelitian meliputi anak kelas 4, 5, dan 6 yang memenuhi kriteria inklusi dan eksklusi. Kriteria inklusi pada penelitian ini antara lain anak yang sudah tinggal di daerah penelitian minimal selama 6 bulan dan bersedia menjadi subjek selama penelitian berlangsung, sedangkan kriteria eksklusi meliputi: anak pindahan dari luar kecamatan lokasi penelitian, tidak tinggal bersama orang tua, serta menderita penyakit infeksi kronis. Jumlah sampel dihitung berdasarkan rumus pendugaan $\mathrm{P}$ dalam jarak "d" persen (12), sehingga diperoleh sebanyak 247 orang sampel yang ditentukan dengan 2 tahap penentuan. Tahap pertama dengan melakukan resurvei pada 4 kecamatan untuk menentukan tingkat endemisitas dan tahap kedua penentuan SD secara purposive. Sampel pada tiap kecamatan ditentukan secara systematic random sampling.

\section{Jenis data dan cara pengumpulan data}

Status GAKY dan tingkat endemisitas Tingkat keparahan GAKY dikelompokkan menjadi GAKY dan nonGAKY, sedangkan tingkat endemisitas GAKY suatu daerah ditentukan berdasarkan indikator TGR yang dikategorikan menjadi 4 kategori menurut WHO (13), yaitu: nonendemis (TGR $<5 \%$ ), endemis ringan (TGR $5,0-19,9 \%$ ), endemis sedang ( $T G R=20,0-29,9 \%$ ), dan endemis berat (TGR $\geq 30 \%$ ).

Palpasi, kadar EYU, kadar tiosianat urin, asupan yodium, dan asupan goitrogenik Palpasi merupakan salah satu cara penentuan ukuran pembesaran kelenjar tiroid yang dikategorikan oleh WHO (13) menjadi tiga, antara lain: grade 0 (tidak ada gondok yang teraba atau terlihat), grade 1 (pembesaran tiroid teraba, tetapi tidak terlihat jika leher pada posisi normal), grade 2 (pembesaran tiroid teraba dan terlihat pada posisi normal).

Kadar EYU dan kadar tiosianat urin diperoleh dari urin pagi sampel, masing-masing menggunakan ammonium persulfate digestion method dan Bradbury method. Kategori kadar EYU menurut WHO (13) yaitu kurang apabila EYU $<100 \mu \mathrm{g} / \mathrm{L}$, cukup apabila EYU antara 100-199 $\mu \mathrm{g} / \mathrm{L}$, lebih apabila EYU antara 200-299 $\mu \mathrm{g} / \mathrm{L}$, dan sangat kelebihan apabila EYU $\geq 300 \mu \mathrm{g} / \mathrm{L}$.

Jumlah asupan yodium dan golongan tiosianat sampel melalui konsumsi makanan diukur dengan metode food recall dan food frequency questionnaire (FFQ). Asupan yodium dikategorikan menjadi kurang (asupan yodium $<120 \mu \mathrm{g} / \mathrm{hari}$ ) dan cukup (asupan yodium $\geq 120 \mu \mathrm{g} /$ hari) (14), sedangkan asupan golongan tiosianat dikelompokkan menjadi tinggi (asupan goitrogenik $>10 \mathrm{mg} / \mathrm{kg} /$ hari) dan rendah (asupan goitrogenik $\leq 10 \mathrm{mg} / \mathrm{kg} /$ hari) (15).

\section{Analisis data}

Analisis data meliputi analisis univariat untuk menggambarkan karakteristik sampel dan analisis bivariat untuk mengetahui hubungan antara variabel bebas dengan variabel terikat menggunakan chi square dan uji korelasi. Analisis bivariat juga digunakan untuk melihat perbedaan status GAKY berdasarkan endemitas dengan menggunakan uji anova.

\section{HASIL DAN BAHASAN}

\section{Karakteristik sampel}

Sampel berjumlah 247 orang yang terdiri dari $49,4 \%$ lakilaki dan $50,6 \%$ perempuan. Sebagian besar $(55,8 \%)$ sampel berumur 10-11 tahun, duduk di bangku kelas 6 SD sebanyak 
$34 \%$, memiliki jumlah anggota keluarga $\leq 7$ sebanyak $62,3 \%$, pendidikan ayah dan ibu yang terbanyak adalah SLTA masingmasing sebanyak $35,6 \%$ dan $34,4 \%$ dengan pekerjaan yang paling banyak digeluti adalah petani masing-masing sebanyak $76,2 \%$ dan $79,4 \%$.

Dilihat dari asupan gizinya, sebagian besar $(96,4 \%)$ sampel memiliki asupan energi $<80 \%$ AKG (angka kecukupan gizi), sebanyak $71,7 \%$ sampel memiliki asupan energi $\geq 80 \%$ AKG, dan 100\% memiliki asupan Fe < 80\% AKG. Karakteristik sampel penelitian secara lengkap disajikan pada Tabel 1.

\section{Status dan tingkat endemisitas GAKY}

TGR merupakan salah satu indikator untuk menentukan status GAKY pada masyarakat dengan metode palpasi/ perabaan. Distribusi sampel berdasarkan hasil palpasi dan daerah endemisitas dapat dilihat pada Tabel 2. Berdasarkan tabel tersebut, ditemukan masing-masing 61 anak $(24,7 \%)$ dan 11 anak (4,5\%) dengan kelenjar gondok grade 1 dan grade 2 . Persentase anak perempuan yang menderita GAKY lebih banyak dibandingkan laki-laki, masing-masing sebesar $53 \%$ dan $47 \%$.

TABEL 1. Karakteristik sampel penelitian

\begin{tabular}{|c|c|c|c|c|c|c|}
\hline \multirow{2}{*}{ Karakteristik } & \multirow[b]{2}{*}{ Jumlah } & \multirow[b]{2}{*}{$\%$} & \multicolumn{4}{|c|}{$\begin{array}{l}\text { Tingkat endemisitas } \\
\end{array}$} \\
\hline & & & $\begin{array}{c}\text { Nonendemis } \\
(\%)\end{array}$ & $\begin{array}{c}\text { Ringan } \\
(\%)\end{array}$ & $\begin{array}{c}\text { Sedang } \\
(\%)\end{array}$ & $\begin{array}{c}\text { Berat } \\
(\%)\end{array}$ \\
\hline \multicolumn{7}{|l|}{ Kelas } \\
\hline 4 & 82 & 33,2 & 22,0 & 25,6 & 29,3 & 23,2 \\
\hline 5 & 81 & 32,8 & 22,2 & 24,7 & 23,5 & 29,6 \\
\hline 6 & 84 & 34,0 & 31,0 & 22,6 & 22,6 & 23,8 \\
\hline \multicolumn{7}{|l|}{ Umur } \\
\hline$<10$ & 48 & 19,4 & 27,1 & 31,3 & 29,2 & 12,5 \\
\hline $10-11$ & 138 & 55,8 & 23,9 & 24,6 & 28,3 & 23,2 \\
\hline$>11$ & 61 & 24,8 & 26,2 & 18,0 & 14,8 & 41,0 \\
\hline \multicolumn{7}{|l|}{ Jenis kelamin } \\
\hline Laki-laki & 122 & 49,4 & 24,6 & 20,5 & 27,0 & 27,9 \\
\hline Perempuan & 125 & 50,6 & 25,6 & 28,0 & 23,2 & 23,2 \\
\hline \multicolumn{7}{|l|}{ Jumlah anggota keluarga } \\
\hline$\leq 7$ & 154 & 62,3 & 29,9 & 23,4 & 29,9 & 16,9 \\
\hline$\overline{>} 7$ & 93 & 37,7 & 17,2 & 25,8 & 17,2 & 39,8 \\
\hline \multicolumn{7}{|l|}{ Pendidikan ayah } \\
\hline Tidak sekolah & 7 & 2,8 & 28,6 & 0 & 42,9 & 28,6 \\
\hline SD & 57 & 23,1 & 31,6 & 21,1 & 17,5 & 29,8 \\
\hline SLTP & 85 & 34,4 & 27,1 & 16,5 & 22,4 & 34,1 \\
\hline SLTA & 88 & 35,6 & 21,6 & 31,8 & 31,8 & 14,8 \\
\hline D3/perguruan tinggi & 10 & 4,1 & 0 & 60,0 & 20,0 & 20,0 \\
\hline \multicolumn{7}{|l|}{ Pendidikan ibu } \\
\hline Tidak sekolah & 3 & 1,2 & 33,3 & 0 & 66,7 & 0 \\
\hline SD & 72 & 29,2 & 34,7 & 18,1 & 12,5 & 34,7 \\
\hline SLTP & 78 & 31,6 & 24,4 & 15,4 & 25,6 & 34,6 \\
\hline SLTA & 85 & 34,4 & 20,0 & 36,5 & 32,9 & 10,6 \\
\hline D3/perguruan tinggi & 9 & 3,6 & 0 & 44,4 & 33,3 & 22,2 \\
\hline \multicolumn{7}{|l|}{ Pekerjaan ayah } \\
\hline Tidak bekerja & 4 & 1,6 & 75,0 & 25,0 & 0 & 0 \\
\hline Buruh & 6 & 2,4 & 16,7 & 50,0 & 33,3 & 0 \\
\hline Pedagang/wiraswasta & 24 & 9,7 & 12,5 & 75,0 & 8,3 & 4,2 \\
\hline Petani & 188 & 76,2 & 29,3 & 12,2 & 26,6 & 31,9 \\
\hline Pegawai swasta & 7 & 2,8 & 0 & 28,6 & 71,4 & 0 \\
\hline PNS/Polri/TNI & 18 & 7,3 & 0 & 72,2 & 16,7 & 11,1 \\
\hline \multicolumn{7}{|l|}{ Pekerjaan Ibu } \\
\hline Tidak Bekerja & 8 & 3,2 & 25,5 & 62,5 & 12,5 & 0 \\
\hline Pedagang/wiraswasta & 27 & 10,9 & 40,7 & 48,1 & 7,4 & 3,7 \\
\hline Petani & 196 & 79,4 & 24,5 & 17,3 & 27,0 & 31,1 \\
\hline PNS/Polri/TNI & 16 & 6,5 & 6,3 & 50,0 & 37,5 & 6,3 \\
\hline \multicolumn{7}{|l|}{ Asupan energi (kal) } \\
\hline$<80 \%$ AKG & 238 & 96,4 & 25,6 & 23,5 & 24,8 & 26,1 \\
\hline$\geq 80 \%$ AKG & 9 & 3,6 & 11,1 & 44,5 & 33,3 & 11,1 \\
\hline \multicolumn{7}{|l|}{ Asupan protein $(\mathrm{g})$} \\
\hline$<80 \%$ AKG & 70 & 28,3 & 22,9 & 10,0 & 27,1 & 40,0 \\
\hline$\geq 80 \%$ AKG & 177 & 71,7 & 26,0 & 29,9 & 24,3 & 19,8 \\
\hline \multicolumn{7}{|l|}{ Asupan Fe (mg) } \\
\hline$<80 \%$ AKG & 247 & 100 & 25,1 & 24,3 & 25,1 & 25,5 \\
\hline$\geq 80 \%$ AKG & 0 & 0 & 0 & 0 & 0 & 0 \\
\hline
\end{tabular}


TGR juga digunakan untuk menentukan tingkat endemisitas GAKY. Gambar 1 menunjukkan perbedaan prevalensi TGR Kecamatan Silimapungga-pungga, Kecamatan Sidikalang, Kecamatan Silahi Sabungan, Kecamatan Parbuluan, dan Kabupaten Dairi tahun 1998 dan tahun 2006. Berdasarkan gambar tersebut diketahui Kecamatan Silimapungga-pungga berubah dari endemis ringan menjadi endemis sedang, Kecamatan Sidikalang berubah dari endemis sedang menjadi endemis ringan, dan Kecamatan Silahi Sabungan berubah dari endemis ringan menjadi nonendemis. Walau demikian, satu kecamatan masih tetap termasuk kategori endemis berat, yaitu Kecamatan Parbuluan.

Berdasarkan hasil resurvei tahun 2006, prevalensi TGR Kabupaten Dairi sebesar 19,37\% yang termasuk ke dalam kategori endemis ringan. Hasil ini sudah jauh lebih rendah dibandingkan hasil survei evaluasi gondok TGR Kabupaten Dairi tahun 2003 sebesar 33,9 \% yang termasuk daerah endemis berat. Namun demikian, angka ini masih lebih tinggi dibandingkan TGR Provinsi Sumatra Utara sebesar 5,3\% dan TGR Indonesia sebesar 11,1\% (13).

Penurunan TGR ini disebabkan konsumsi garam di Kabupaten Dairi sudah baik karena sudah mengandung yodium. Hasil pemeriksaan terhadap beberapa garam yang dibawa sampel membuktikan bahwa semua garam sudah mengandung yodium, begitu pula hasil pemeriksaan terhadap garam komersial yang dilakukan oleh Dinas Kesehatan
Provinsi Sumatra Utara tahun 2006 bahwa 100\% garam yang beredar di Kabupaten Dairi sudah mengandung yodium (1).

Berdasarkan tingkat endemisitas, pada daerah endemisitas berat terdapat 5 anak $(7,9 \%)$ dengan kelenjar gondok grade 2 , sedangkan pada daerah nonendemis tidak ada anak dengan kelenjar gondok grade 2. Jumlah anak dengan kelenjar gondok grade 0 pada daerah endemis berat hanya 33 orang $(52,4 \%)$ dan yang terbanyak terdapat di daerah nonendemis sebanyak 58 orang $(93,5 \%)$.

\section{Kadar EYU dan perbedaannya berdasarkan tingkat endemisitas}

EYU merupakan salah satu indikator yang menggambarkan status kekurangan yodium karena sebagian besar konsumsi yodium dikeluarkan melalui urin. Distribusi sampel berdasarkan kadar EYU disajikan pada Gambar 2. Ada $25,5 \%$ anak yang mempunyai kadar EYU $<100 \mu \mathrm{g} / \mathrm{L}$ dan $8,9 \%$ anak dengan kadar EYU > $300 \mu \mathrm{g} / \mathrm{L}$. Kadar EYU yang kurang menunjukkan potensi kekurangan yodium, sedangkan kadar EYU yang berlebih berisiko mengalami gangguan kesehatan seperti iodine induced hyperthyroidism (IIH) dan autoimmune thyroid disease (ATD) (1).

Persentase sampel dengan kadar EYU antara 100-199 $\mu \mathrm{g} / \mathrm{L}$ (status yodium optimal) ditemukan paling rendah pada daerah endemis berat yaitu sebanyak $39,7 \%$ dan paling tinggi ditemukan pada daerah endemis ringan yaitu sebanyak $51,7 \%$. Sedangkan persentase sampel dengan kadar EYU antara 50-

TABEL 2. Distribusi sampel berdasarkan hasil palpasi dan tingkat endemisitas total goiter rate (TGR)

\begin{tabular}{lcccccccc}
\hline \multirow{2}{*}{$\begin{array}{c}\text { Tingkat endemisitas } \\
\text { berdasarkan TGR }\end{array}$} & \multicolumn{9}{c}{ Grade } & \multicolumn{3}{c}{ Total } \\
\cline { 2 - 9 } & $\mathbf{n}$ & $\mathbf{0}$ & $\mathbf{n}$ & $\mathbf{9}$ & $\mathbf{n}$ & $\mathbf{\%}$ & $\mathbf{n}$ & $\mathbf{\%}$ \\
\hline Nonendemis & 58 & 93,5 & 4 & 6,5 & 0 & 0 & 62 & 100 \\
Endemis ringan & 37 & 61,7 & 20 & 33,3 & 3 & 5 & 60 & 100 \\
Endemis sedang & 47 & 75,8 & 12 & 19,4 & 3 & 4,8 & 62 & 100 \\
Endemis berat & 33 & 52,4 & 25 & 39,7 & 5 & 7,9 & 63 & 100 \\
Total & $\mathbf{1 7 5}$ & $\mathbf{7 0 , 9}$ & $\mathbf{6 1}$ & $\mathbf{2 4 , 7}$ & $\mathbf{1 1}$ & $\mathbf{4 , 5}$ & $\mathbf{2 4 7}$ & $\mathbf{1 0 0}$ \\
\hline
\end{tabular}

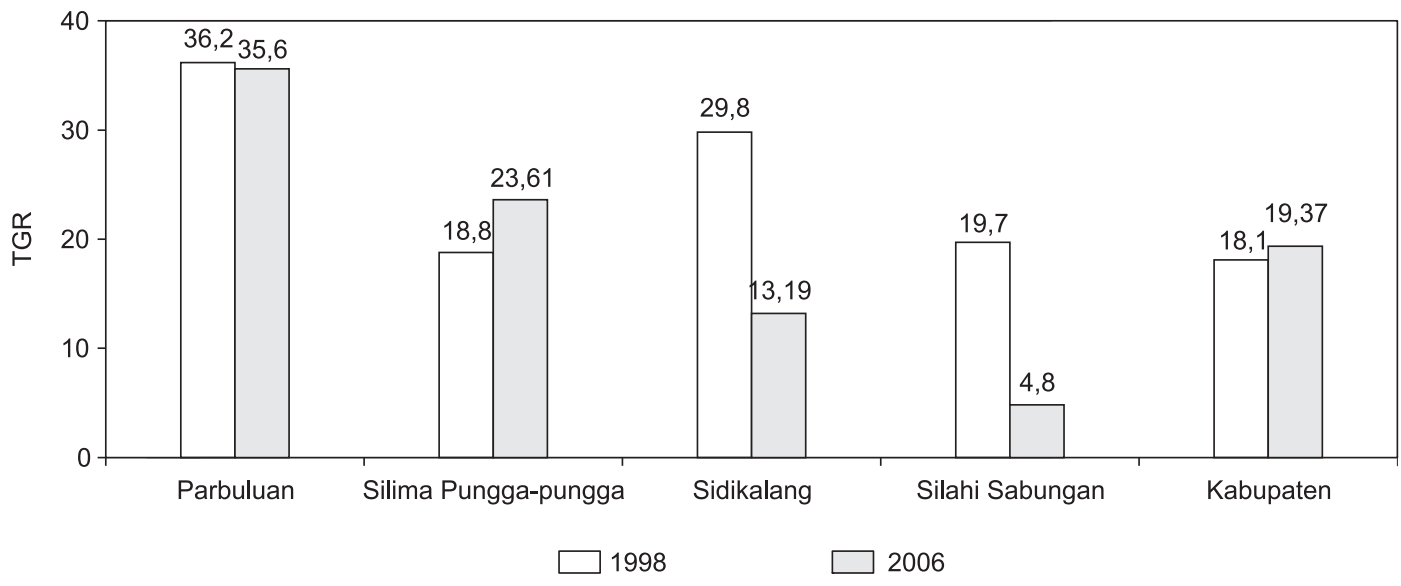

GAMBAR 1. Perubahan prevalensi total goiter rate (TGR) 4 kecamatan di Kabupaten Dairi dan Kabupaten Dairi tahun 1998 dan 2006 berdasarkan endemisitas 


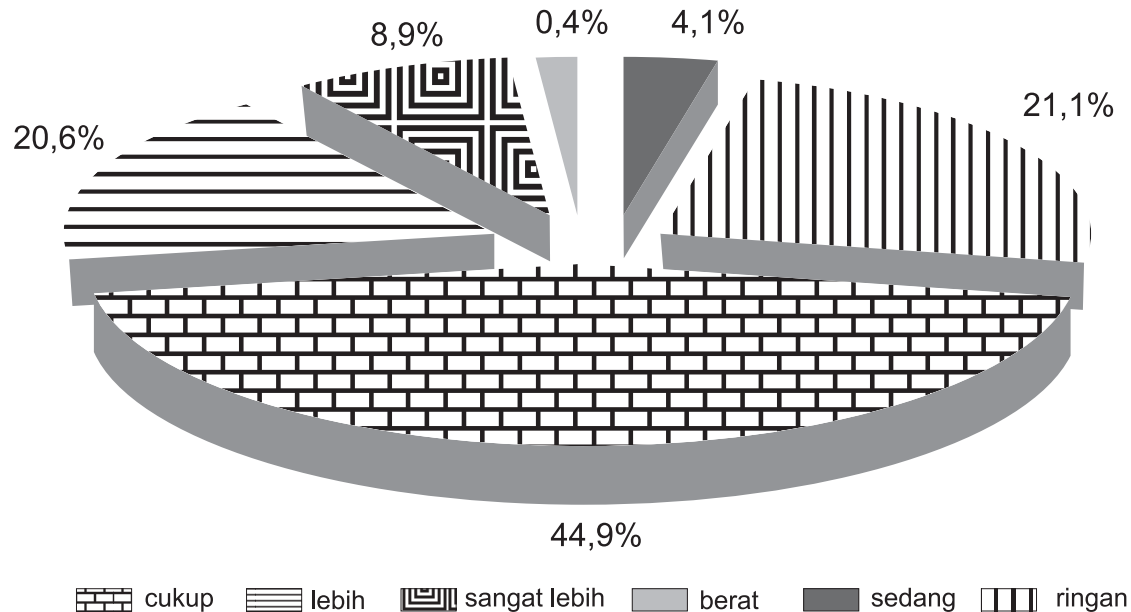

GAMBAR 2. Distribusi sampel berdasarkan ekskresi yodium urin (EYU)

$99 \mu \mathrm{g} / \mathrm{L}$ (kekurangan yodium ringan) ditemukan paling tinggi pada daerah endemis sedang yaitu sebesar $30,6 \%$, diikuti daerah endemis berat (25,4\%). Kekurangan yodium sedang (EYU antara $20-49 \mu \mathrm{g} / \mathrm{L}$ ) paling tinggi juga ditemukan pada daerah endemis berat yaitu sebesar 6,3\%. Dengan demikian anak yang tinggal di daerah endemis sedang dan berat lebih banyak yang mengalami kekurangan yodium berdasarkan EYU. Demikian juga dengan anak yang sangat kelebihan yodium, paling banyak ditemukan pada daerah endemis berat dengan persentase sebesar 17,5\% (Gambar 3).

Pada penelitian ini, median EYU Kabupaten Dairi sebesar $150 \mu \mathrm{g} / \mathrm{L}$ dan termasuk daerah yang berstatus yodium cukup menurut kategori WHO (median 100-199 $\mu \mathrm{g} / \mathrm{L}$ ). Berdasarkan survei gondok nasional tahun 2003 , hasil ini masih lebih tinggi dibandingkan EYU Provinsi Sumatra sebesar 13,2\% dan EYU Indonesia sebesar 16,3\%. Median EYU yang paling tinggi berdasarkan tingkat endemisitas di Kabupaten Dairi adalah daerah nonendemis yaitu sebesar $182 \mu \mathrm{g} / \mathrm{L}$, sedangkan median yang paling rendah adalah daerah endemis berat yaitu sebesar $124 \mu \mathrm{g} / \mathrm{L}$ (Tabel 3). Hasil ini menunjukkan median EYU berdasarkan tingkat endemisitas masih tergolong status yodium cukup. Makin berat tingkat endemis suatu daerah, median kadar EYU makin rendah.

\section{Asupan yodium serta perbedaannya berdasarkan tingkat endemisitas}

Di daerah penelitian, sumber yodium berasal dari ikan terutama ikan laut kering (ikan asin dan ikan teri), sedangkan susu dan ikan laut segar sangat jarang dan bahkan tidak pernah dikonsumsi oleh penduduk. Menurut Almatsier (16), sumber utama yodium dapat berasal dari bahan makanan hewani, terutama ikan laut, kerang-kerangan, dan rumput laut.

Rata-rata asupan yodium anak sekolah pada penelitian ini sebesar 138,3 \pm 40,5 $\mu \mathrm{g} / \mathrm{hari}$ (IK 95\%: 133,2-143,4) dan

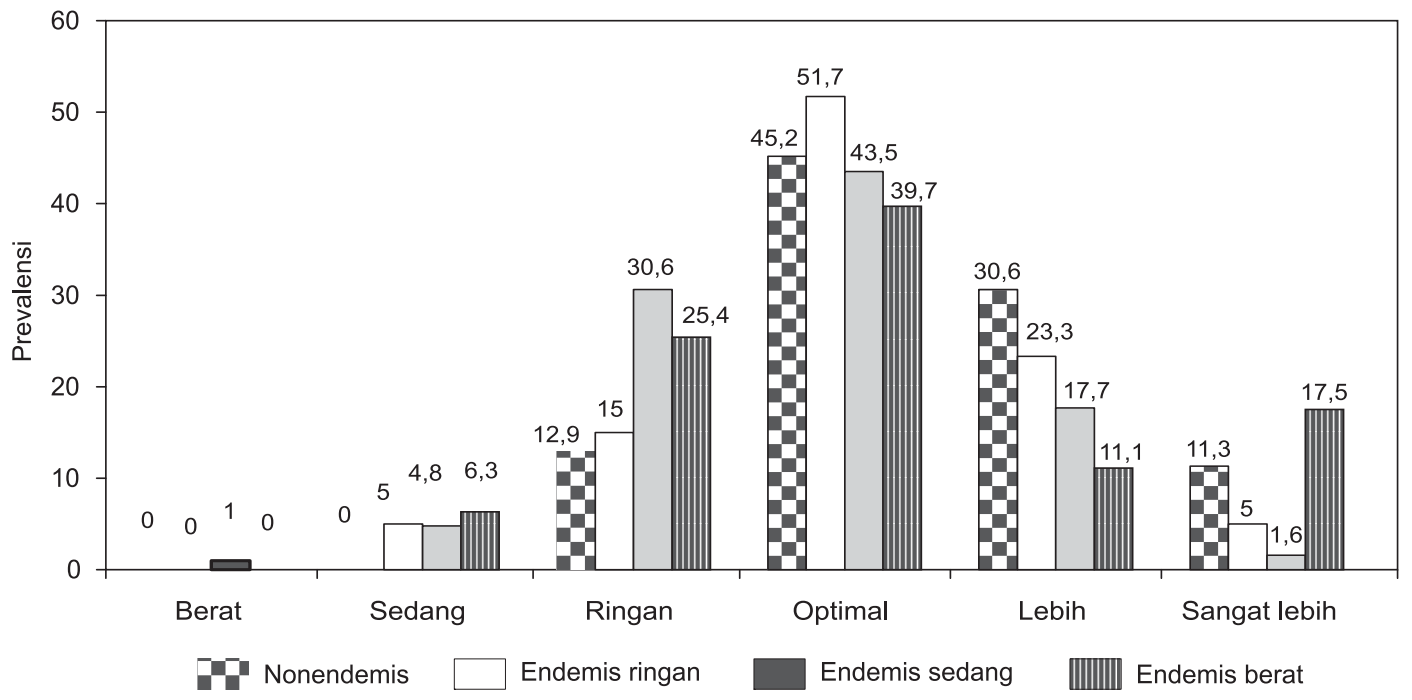

GAMBAR 3. Distribusi sampel berdasarkan total goiter rate (TGR) dan ekskresi yodium urin (EYU) 
TABEL 3. Distribusi median ekskresi yodium urin (EYU) sampel berdasarkan tingkat endemisitas total goiter rate (TGR)

\begin{tabular}{|c|c|c|c|c|c|c|}
\hline \multirow{2}{*}{$\begin{array}{c}\text { Tingkat endemisitas } \\
\text { berdasarkan TGR }\end{array}$} & \multirow[b]{2}{*}{$\mathbf{n}$} & \multicolumn{4}{|c|}{ EYU } & \multirow[b]{2}{*}{$\mathbf{p}$} \\
\hline & & Median & SD & IK 95\% & $\begin{array}{l}\text { Minimal- } \\
\text { maksimal }\end{array}$ & \\
\hline Nonendemis & 62 & 182 & 79,5 & $168,2-208,6$ & $54-358$ & \\
\hline Endemis ringan & 60 & 163 & 71,2 & $147,0-183,8$ & $28-313$ & \\
\hline Endemis sedang & 62 & 130 & 71,1 & $116,7-152,8$ & $12-388$ & $0,006^{*}$ \\
\hline Endemis berat & 63 & 124 & 109,6 & $139,6-194,9$ & $30-468$ & \\
\hline Total & 247 & 150 & 86,2 & $153,1-174,8$ & $12-468$ & \\
\hline
\end{tabular}

di antara seluruh sampel, sebanyak $32 \%$ anak sekolah memiliki asupan yodium kurang dan $68 \%$ lainnya memiliki asupan yodium kurang. Berdasarkan Widyakarya Nasional Pangan dan Gizi tahun 2004, kecukupan yodium anak berumur 7-12 tahun adalah $120 \mu \mathrm{g} / \mathrm{hari}$. Dengan demikian, rata-rata asupan yodium per hari anak sekolah di Kabupaten Dairi termasuk dalam kategori cukup.

Distribusi sampel berdasarkan asupan yodium dan tingkat endemisitas TGR disajikan pada Tabel 4. Sampel pada daerah nonendemis mempunyai peluang kekurangan yodium sebesar $45,2 \%$, sedangkan pada daerah endemis berat hanya berpeluang kekurangan yodium sebesar $19,0 \%$. Persentase anak yang paling banyak kekurangan yodium berada pada daerah nonendemis yaitu sebesar $45,2 \%$.

Distribusi rata-rata asupan yodium berdasarkan tingkat endemisitas dapat dilihat pada Tabel 5. Dari tabel tersebut, rata-rata asupan yodium yang paling tinggi adalah daerah endemis berat yaitu sebesar $154,7 \pm 47,2 \mu \mathrm{g} / \mathrm{hari}$, sedangkan asupan yodium paling rendah adalah daerah nonendemis yaitu sebesar 121,7 $\pm 34,7 \mu \mathrm{g} /$ hari. Hasil uji statistik membuktikan adanya perbedaan asupan yodium pada keempat daerah endemis $(p<0,05)$ dan analisis Ianjutan Duncan membuktikan bahwa daerah yang memiliki asupan yodium paling berbeda adalah daerah endemis berat, sedangkan daerah endemis ringan dan sedang tidak berbeda. Hal ini dimungkinkan karena penduduk di daerah endemis berat umumnya lebih sering mengkonsumsi ikan laut, sedangkan penduduk di daerah nonendemis umumnya lebih sering mengkonsumsi ikan air tawar.

FFQ digunakan untuk melihat kebiasaan makan seseorang dalam jangka waktu lama dan menggambarkan status kekurangan atau kelebihan asupan makanan (17). Berdasarkan hasil $F F Q$, sumber utama yodium dalam bahan makanan berasal dari ikan laut terutama ikan kering (ikan asin dan ikan teri) dengan frekuensi makan rata-rata 3 kali/hari, padi-padian 3 kali/hari, sayur-sayuran 1 kali/hari, sedangkan daging, susu, dan minyak ikan sangat jarang dimakan. Sumber utama ini erat kaitannya dengan letak Kabupaten Dairi yang berada di daerah dataran tinggi dan jauh dari laut. Makin berat tingkatan endemis suatu daerah, konsumsi ikan laut makin sering.

TABEL 4. Distribusi sampel berdasarkan asupan yodium dan tingkat endemisitas total goiter rate (TGR)

\begin{tabular}{lcccccc}
\hline \multirow{2}{*}{$\begin{array}{c}\text { Tingkat endemisitas } \\
\text { berdasarkan TGR }\end{array}$} & \multicolumn{4}{c}{ Asupan yodium } & \multicolumn{2}{c}{ Total } \\
\cline { 2 - 6 } \multicolumn{1}{c}{ Kurang } & $\mathbf{n}$ & $\mathbf{\%}$ & $\mathbf{n}$ & $\mathbf{\%}$ & $\mathbf{n}$ & $\mathbf{\%}$ \\
\hline Nonendemis & 28 & 45,2 & 34 & 54,8 & 62 & 100 \\
Endemis ringan & 17 & 28,3 & 43 & 71,7 & 60 & 100 \\
Endemis sedang & 21 & 33,9 & 41 & 66,1 & 62 & 100 \\
Endemis berat & 12 & 19,0 & 51 & 81,0 & 63 & 100 \\
Total & $\mathbf{7 8}$ & $\mathbf{3 1 , 6}$ & $\mathbf{1 6 9}$ & $\mathbf{6 8 , 4}$ & $\mathbf{2 4 7}$ & $\mathbf{1 0 0}$ \\
\hline
\end{tabular}

TABEL 5. Distribusi rata-rata asupan yodium sampel berdasarkan tingkat endemisitas total goiter rate (TGR)

\begin{tabular}{|c|c|c|c|c|c|c|}
\hline \multirow{2}{*}{$\begin{array}{c}\text { Tingkat endemisitas } \\
\text { berdasarkan TGR }\end{array}$} & \multirow[b]{2}{*}{$\mathbf{n}$} & \multicolumn{4}{|c|}{ Asupan yodium } & \multirow[b]{2}{*}{$\mathbf{p}$} \\
\hline & & Mean & SD & IK 95\% & $\begin{array}{l}\text { Minimal- } \\
\text { maksimal }\end{array}$ & \\
\hline Nonendemis & 62 & 121,7 & 34,7 & $112,9-130,5$ & $46,9-183,9$ & \\
\hline Endemis ringan & 60 & 137,3 & 32,9 & $128,8-145,8$ & $64,0-207,2$ & \\
\hline Endemis sedang & 62 & 139,3 & 39,4 & $129,3-149,3$ & $65,8-256,1$ & $<0,001^{*}$ \\
\hline Endemis berat & 63 & 154,7 & 47,2 & $142,8-166,6$ & $58,5-294,0$ & \\
\hline Total & 247 & 138,3 & 40,5 & $133,3-143,4$ & $46,9-294,0$ & \\
\hline
\end{tabular}

Keterangan:

* Bermakna $(p<0,05)$ 
Sebaliknya, daerah nonendemis lebih sedikit mengkonsumsi ikan laut dan lebih banyak mengkonsumsi ikan air tawar karena dekat danau yaitu Danau Toba.

Rata-rata skor FFQ adalah 15,63 (IK 95\%: 15,28-15,98). Rata-rata skor paling tinggi adalah endemis ringan dan paling rendah adalah endemis berat diikuti endemis sedang. Hal ini disebabkan asupan yodium endemis ringan lebih beragam karena berada di ibukota kabuputen, sedangkan daerah lain sumber yodium tidak beragam. Hasil uji korelasi antara FFQ yodium dengan GAKY diperoleh nilai $r=-0,019$ dan $p=0,762$ artinya tidak ada hubungan antara FFQ yodium dengan kejadian GAKY. Hal ini diperkuat dengan penelitian Thaha et al. (10) pada anak SD di daerah pantai di Provinsi Maluku yang menunjukkan tidak ada perbedaan yang bermakna skor FFQ bahan makanan sumber yodium antara daerah endemis dan nonendemis.

\section{Hubungan antara asupan yodium dengan kadar EYU}

EYU merupakan salah satu indikator yang menggambarkan status kekurangan yodium, karena sebagian besar konsumsi yodium dikeluarkan melalui urin (18). Tabel 6 menggambarkan hubungan antara asupan yodium dengan kadar EYU. Dari tabel tersebut diketahui sebagian besar sampel memiliki asupan yodium kurang dan akan mempunyai kadar EYU yang juga kurang yaitu sebanyak 44,9\%. Hasil ini jauh lebih tinggi dibandingkan dengan sampel yang memiliki asupan yodium cukup, namun kadar EYU juga kurang yaitu sebanyak 17,2\%.

Hasil uji statistik chi square menunjukkan adanya hubungan antara asupan yodium dengan EYU $(p<0,05)$. Hal ini membuktikan adanya kesesuaian dengan teori yang menyebutkan bahwa untuk mengetahui gambaran asupan yodium seseorang bisa dilihat melalui kadar EYU. Hasil ini diperkuat oleh penelitian Djayusmantoko (9) di Provinsi Jambi yang melaporkan adanya hubungan antara asupan yodium dengan EYU. Penelitian Santoso (11) pada ibu hamil di daerah endemis GAKY di Gunung Kidul juga menjelaskan adanya hubungan antara asupan yodium dengan EYU.

\section{Hubungan antara asupan yodium dengan GAKY}

Tabel 7 menunjukkan hubungan antara asupan yodium dengan status GAKY berdasarkan palpasi. Anak yang memiliki asupan yodium kurang berpeluang menderita GAKY yaitu sebesar $23,1 \%$ dan sampel yang memiliki asupan yodium kurang namun tidak menderita GAKY jumlahnya lebih besar yaitu sebanyak $76,9 \%$. Hasil uji chi square menunjukkan tidak ada hubungan antara tingkat asupan yodium dengan kejadian gondok $(p>0,05)$. Hal ini diduga disebabkan sebagian besar anak, baik yang gondok maupun tidak gondok, memiliki tingkat kecukupan yodium yang cukup dan sumber utama yodium yang hampir sama yaitu berasal dari ikan laut terutama ikan kering. Hasil ini sama dengan penelitian Triyono dan Gunanti (19) di Kabupaten Pasuruan yang membuktikan bahwa tidak ada hubungan antara kejadian gondok dengan asupan yodium dari bahan makanan.

\section{Ekskresi tiosianat urin dan perbedaannya berdasarkan tingkat endemisitas}

Goitrogenik merupakan suatu zat yang menghambat produksi atau penggunaan hormon tiroid oleh kelenjar gondok dan merupakan unsur yang kuat menyebabkan hipotiroidisme (20). Keberadaan zat goitrogenik akan menjadi nyata jika terjadi kekurangan yodium (16). Salah satu jenis goitrogenik dari makanan adalah golongan tiosianat.

Sebanyak $76,9 \%$ sampel pada daerah endemis berat berpotensi mempunyai ekskresi tiosianat urin yang tinggi, demikian juga pada daerah endemis sedang $(75 \%)$. Persentase anak pada endemis berat dan endemis sedang lebih banyak mengkonsumsi bahan makanan yang mengandung tiosianat dibandingkan dengan nonendemis dan

TABEL 6. Distribusi sampel berdasarkan ekskesi yodium urin (EYU) dan asupan yodium

\begin{tabular}{|c|c|c|c|c|c|c|c|c|c|c|}
\hline \multirow{3}{*}{ Asupan yodium } & \multicolumn{4}{|c|}{ EYU } & \multirow{2}{*}{\multicolumn{2}{|c|}{ Total }} & \multirow{3}{*}{$\pi^{2}$} & \multirow{3}{*}{ p } & \multirow{3}{*}{ OR } & \multirow{3}{*}{ IK 95\% } \\
\hline & \multicolumn{2}{|c|}{ Kurang } & \multicolumn{2}{|c|}{ Cukup } & & & & & & \\
\hline & $\mathbf{n}$ & $\%$ & $\mathbf{n}$ & $\%$ & $\mathbf{n}$ & $\%$ & & & & \\
\hline Kurang & 35 & 44,9 & 43 & 55,1 & 78 & 100 & 21,34 & $\leq 0,001^{*}$ & 3,9 & $2,2-7,2$ \\
\hline Cukup & 29 & 17,2 & 140 & 82,8 & 169 & 100 & & & & \\
\hline Total & 64 & 25,9 & 183 & 74,1 & 247 & 100 & & & & \\
\hline
\end{tabular}

Keterangan:

* Bermakna $(p<0,05)$

TABEL 7. Distribusi sampel berdasarkan status gangguan akibat kekurangan yodium (GAKY) dan asup an yodium

\begin{tabular}{|c|c|c|c|c|c|c|c|c|c|c|}
\hline \multirow{3}{*}{ Asupan yodium } & \multicolumn{4}{|c|}{ Status GAKY } & \multirow{2}{*}{\multicolumn{2}{|c|}{ Total }} & \multirow{3}{*}{$\pi^{2}$} & \multirow{3}{*}{ p } & \multirow{3}{*}{ OR } & \multirow{3}{*}{ IK 95\% } \\
\hline & \multicolumn{2}{|c|}{ GAKY } & \multicolumn{2}{|c|}{ Non-GAKY } & & & & & & \\
\hline & $\mathbf{n}$ & $\%$ & $\mathbf{n}$ & $\%$ & $\mathbf{n}$ & $\%$ & & & & \\
\hline Kurang & 18 & 23,1 & 60 & 76,9 & 77 & 100 & 2,03 & 0,154 & 0,63 & $0,34-1,18$ \\
\hline Cukup & 54 & 32,0 & 115 & 68,0 & 170 & 100 & & & & \\
\hline Total & 72 & 29,1 & 169 & 70,9 & 247 & 100 & & & & \\
\hline
\end{tabular}


endemis ringan (Tabel 8). Asupan tiosianat di daerah penelitian berasal dari bahan makanan seperti: daun singkong, kol, selada air, bayam, kangkung, jengkol, ubi, dan singkong.

Tabel 9 menggambarkan distribusi kadar tiosianat dalam urin berdasarkan tingkat endemisitasnya. Dari tabel tersebut dapat diketahui rata-rata kadar tiosianat dalam urin anak sekolah penelitian ini adalah $1,15 \mu \mathrm{g} / \mathrm{mL}$ (IK 95\%: 0,79-1,51 $\mu \mathrm{g} / \mathrm{ml}$ ), median sebesar $0,8 \mu \mathrm{g} / \mathrm{mL}$, dan SD sebesar $1,26 \mu \mathrm{g} /$ $\mathrm{mL}$. Rata-rata kadar ekskresi tiosianat dalam urin yang paling tinggi ada di daerah endemis sedang sebesar $1,78 \mu \mathrm{g} / \mathrm{mL}$ (IK 95\%: 0,54 - 5,94) dan endemis berat sebesar 1,73 $\mu \mathrm{g} /$ $\mathrm{mL}$, sedangkan yang paling rendah terdapat pada daerah endemis ringan yaitu $0,53 \mu \mathrm{g} / \mathrm{mL}$.

Median kadar ekskresi tiosianat dalam urin yang paling tinggi seperti tertera dalam Tabel 9 ada di daerah endemis sedang yaitu $1,41 \mu \mathrm{g} / \mathrm{mL}$, sedangkan median yang paling rendah ada di daerah endemis ringan dan nonendemis yaitu sebesar $0,45 \mu \mathrm{g} / \mathrm{mL}$.

Hasil uji statistik membuktikan adanya perbedaan ratarata kadar tiosianat dalam urin pada keempat kecamatan di Kabupaten Dairi berdasarkan tingkat endemisitasnya $(p<$ $0,05)$. Analisis lanjutan Duncan membuktikan adanya perbedaan antara daerah nonendemis dan endemis ringan serta antara daerah endemis sedang dan endemis berat. Daerah endemis berat dan sedang menghasilkan sayursayuran yang mudah diperoleh, sehingga banyaknya konsumsi sayuran menyebabkan asupan tiosianat menjadi lebih banyak pula. Sebaliknya, daerah endemis ringan merupakan daerah perkotaan dan daerah nonendemis tidak menghasilkan sayur-sayuran yang menyebabkan sayuran (sumber tiosianat) tidak terdapat dalam jumlah besar.
Asupan tiosianat serta perbedaan berdasarkan tingkat endemisitas

Selain dari ekskresi tiosianat urin, kadar tiosianat juga dapat diketahui dari konsumsi bahan makanan. Bahan makanan yang kaya sumber tiosianat antara lain: ubi kayu, hasil olahan ubi kayu, lobak, kol, rebung, ubi jalar, dan buncis. Pada penelitian ini, makanan sumber tiosianat yang sering dikonsumsi adalah daun singkong, kol, selada air, bayam, kangkung, jengkol, ubi, dan singkong. Rata-rata konsumsi tiosianat pada penelitian ini adalah $6,7 \mathrm{mg} / \mathrm{kg}$. Menurut $\mathrm{FAO} /$ WHO, rata-rata konsumsi ini masih dalam batas aman sianida, yaitu $10 \mathrm{mg} / \mathrm{kg}$ berat kering (15).

Selain itu, masih terdapat $20,6 \%$ sampel yang mengkonsumsi tiosianat $>10 \mathrm{mg} / \mathrm{hari}$. Distribusi sampel berdasarkan TGR dan asupan tiosianat disajikan pada Tabel 10. Dari tabel tersebut dapat dijelaskan bahwa terdapat $31,7 \%$ sampel pada endemis berat yang mengkonsumsi tiosianat lebih tinggi daripada batas yang dianjurkan, sedangkan pada daerah nonendemis jauh lebih rendah yaitu sebanyak $14,5 \%$ sampel.

Berdasarkan tingkat endemisitasnya, rata-rata asupan tiosianat paling tinggi ada di daerah endemis berat yaitu sebesar $8,9 \mathrm{mg} / \mathrm{kg} / \mathrm{hari}$ dan paling rendah adalah daerah nonendemis yaitu $5,2 \mathrm{mg} / \mathrm{kg} / \mathrm{hari}$. Median asupan tiosianat yang paling tinggi berdasarkan tingkat endemisitasnya adalah daerah endemis berat yaitu $7,6 \mathrm{mg} / \mathrm{kg}$ dengan standar deviasi $6,1 \mathrm{mg} / \mathrm{kg}$, sedangkan median yang paling rendah adalah daerah nonendemis yaitu sebesar $4,1 \mathrm{mg} / \mathrm{kg}$ dengan standar deviasi 3,9 mg/kg (Tabel 11).

Hasil uji statistik didapat ada perbedaan rata-rata asupan tiosianat berdasarkan tingkat endemisitas $(p<0,05)$. Analisis lanjutan Duncan menunjukkan bahwa daerah yang memiliki rata-rata asupan tiosianat paling berbeda adalah daerah

TABEL 8. Distribusi sampel berdasarkan kadar ekskresi tiosianat urin dan tingkat endemisitas

\begin{tabular}{|c|c|c|c|c|c|c|}
\hline \multirow{3}{*}{$\begin{array}{c}\text { Tingkat endemisitas berdasarkan } \\
\text { total goiter rate (TGR) }\end{array}$} & \multicolumn{4}{|c|}{ Ekskresi tiosianat urin } & \multirow{2}{*}{\multicolumn{2}{|c|}{ Total }} \\
\hline & \multicolumn{2}{|c|}{ Tinggi } & \multicolumn{2}{|c|}{ Rendah } & & \\
\hline & $\mathbf{n}$ & $\%$ & n & $\%$ & $\mathbf{n}$ & $\%$ \\
\hline Nonendemis & 3 & 23,1 & 10 & 76,9 & 13 & 100 \\
\hline Endemis ringan & 3 & 25,0 & 9 & 75,0 & 12 & 100 \\
\hline Endemis sedang & 9 & 75,0 & 3 & 25,0 & 12 & 100 \\
\hline Endemis berat & 10 & 76,9 & 3 & 23,1 & 13 & 100 \\
\hline Total & 21 & 42,0 & 29 & 58,0 & 50 & 100 \\
\hline
\end{tabular}

TABEL 9. Distribusi kadar ekskresi tiosianat urin berdasarkan tingkat endemisitas total goiter rate (TGR)

\begin{tabular}{|c|c|c|c|c|c|c|c|}
\hline \multirow{2}{*}{$\begin{array}{c}\text { Tingkat endemisitas berdasarkan } \\
\text { total goiter rate (TGR) }\end{array}$} & \multirow{2}{*}{$\mathbf{n}$} & \multicolumn{5}{|c|}{ Ekskresi tiosianat urin } & \multirow{2}{*}{$\mathbf{p}$} \\
\hline & & Mean & Median & SD & IK 95\% & $\begin{array}{l}\text { Minimal- } \\
\text { maksimal }\end{array}$ & \\
\hline Nonendemis & 13 & 0,58 & 0,45 & 0,34 & $0,37-0,78$ & $0,18-1,26$ & \\
\hline Endemis ringan & 12 & 0,53 & 0,45 & 0,34 & $0,32-0,75$ & $0,18-1,08$ & \\
\hline Endemis sedang & 12 & 1,78 & 1,41 & 1,51 & $0,82-2,74$ & $0,54-5,94$ & $0,007^{*}$ \\
\hline Endemis berat & 13 & 1,73 & 1,15 & 1,65 & $0,73-2,72$ & $0,54-6,48$ & \\
\hline Total & 50 & 1,15 & 0,8 & 1,26 & $0,79-1,51$ & $0,18-6,48$ & \\
\hline
\end{tabular}

Keterangan:

* Bermakna $(p<0,05)$ 
TABEL 10. Distribusi sampel berdasarkan asupan tiosianat dan tingkat endemisitas total goiter rate (TGR)

\begin{tabular}{lcccccc}
\hline \multirow{2}{*}{ Tingkat endemisitas berdasarkan TGR } & \multicolumn{3}{c}{ Asupan tiosianat } & \multicolumn{2}{c}{ Total } \\
\cline { 2 - 6 } & \multicolumn{2}{c}{ Tinggi } & \multicolumn{2}{c}{ Rendah } & \multicolumn{2}{c}{$\mathbf{~}$} \\
\cline { 2 - 6 } & $\mathbf{n}$ & $\mathbf{\%}$ & $\mathbf{n}$ & $\mathbf{\%}$ & $\mathbf{n}$ & $\mathbf{\%}$ \\
\hline Nonendemis & 9 & 14,5 & 53 & 85,5 & 62 & 100 \\
Endemis ringan & 13 & 21,7 & 47 & 78,3 & 60 & 100 \\
Endemis sedang & 9 & 14,5 & 53 & 85,5 & 62 & 100 \\
Endemis berat & 20 & 31,7 & 43 & 68,3 & 63 & 100 \\
Total & $\mathbf{5 1}$ & $\mathbf{2 0 , 6}$ & $\mathbf{1 9 6}$ & $\mathbf{7 9 , 4}$ & $\mathbf{2 4 7}$ & $\mathbf{1 0 0}$ \\
\hline
\end{tabular}

TABEL 11. Distribusi asupan tiosianat berdasarkan tingkat endemisitas total goiter rate (TGR)

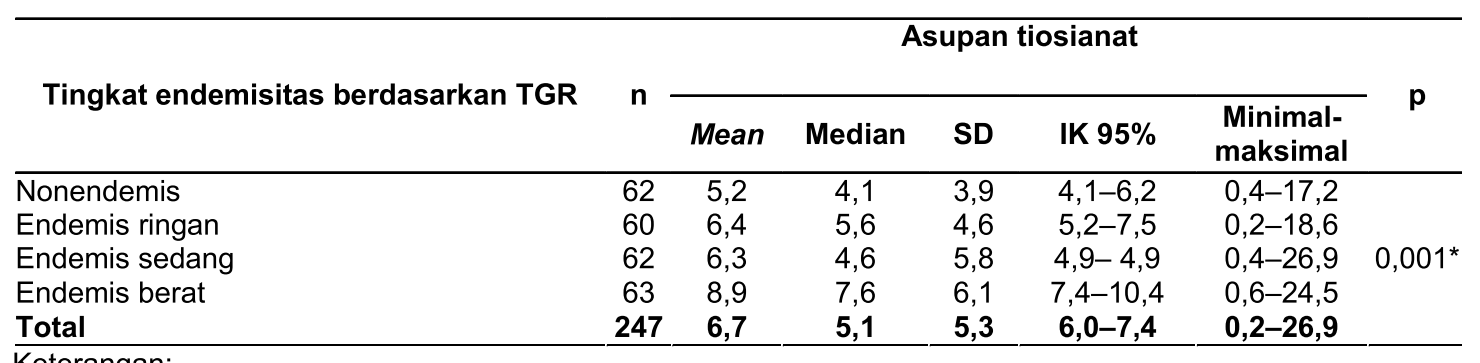

Keterangan:

* Bermakna $(p<0,05)$

endemis berat, sedangkan daerah nonendemis, endemis ringan, dan endemis sedang tidak berbeda.

Hasil FFQ dan food recall, daerah nonendemis lebih sedikit mengkonsumsi bahan makanan yang mengandung unsur goitrogenik disebabkan sumber goitrogenik pada daerah nonendemis lebih banyak berasal dari luar. Rata-rata skor hasil FFQ penelitian ini sebesar 10,37 (IK 95\%: 9,93-10,62) dan SD 2,76. Uji korelasi antara skor FFQ tiosianat dengan GAKY diperoleh $r=0,083$ dan $p=0,194$ artinya tidak ada hubungan antara FFQ tiosianat dengan kejadian GAKY $(p>0,05)$. Hal ini mungkin disebabkan pola makan sampel yang non-GAKY dengan yang GAKY adalah sama atau tidak berbeda. Ini dapat dilihat dari batas atas dan batas rendah yang sangat kecil. Hasil penelitian Saraswati (21) di Kabupaten Karawang menunjukkan bahwa tidak ada beda pola makan antara sampel non-GAKY dan GAKY. Penelitian Sumby (22) di Kabupaten Ende Nusa Tenggara Timur juga menyatakan tidak ada hubungan frekuensi konsumsi bahan goitrogenik dengan kejadian gondok. Thaha et al. (10) tidak menemukan perbedaan skor FFQ bahan makanan tiosianat antara daerah endemis dan nonendemis pada anak SD di daerah pantai di Daerah Maluku.

\section{Hubungan antara asupan tiosianat dengan EYU}

Kadar tiosianat juga dapat dilihat dari urin, karena sebagian besar tiosianat dikeluarkan melalui urin. Bila kadar ekskresi tiosianat urin tinggi, maka kemungkinan seseorang juga mengkonsumsi tiosianat dalam jumlah yang tinggi sehingga akan menghambat penyerapan yodium ke dalam kelenjar tiroid.

Antara kadar tiosianat urin dengan kejadian gondok menunjukkan hubungan yang tidak bermakna $(p>0,05)$. Hal ini disebabkan kejadian gondok tidak terjadi dalam sesaat, tetapi sudah berlangsung lama. Kadar tiosianat dalam urin juga akan mempengaruhi kadar EYU. Hasil uji statistik menunjukkan tidak ada hubungan antara kadar ekskresi tiosianat urin dengan EYU ( $r=-141, p=329)$. Namun demikian, dilihat dari kurva regresi pada Gambar 4 menunjukkan ada hubungan antara ekskresi tiosianat urin dengan EYU. Makin tinggi kadar ekskresi tiosianat dalam urin, kadar EYU juga makin turun.

\section{Hubungan antara asupan tiosianat dengan GAKY}

Tabel 12 menunjukkan hubungan antara asupan tiosianat dengan GAKY. Dari tabel tersebut dapat diketahui bahwa sampel yang memiliki asupan tiosianat tinggi berpeluang menderita gondok sebesar $60,8 \%$, sedangkan yang memiliki asupan tiosianat rendah hanya berpeluang menderita gondok sebesar 20,9\%. Dengan demikian, anak yang memiliki asupan tiosianat tinggi akan berpeluang lebih besar menderita gondok dibandingkan anak yang memiliki asupan tiosianat rendah.

Hasil uji korelasi antara asupan tiosianat dengan GAKY juga membuktikan adanya hubungan yang bermakna $(p<0,05)$. Menurut Linder (3), tiosianat akan berkompetisi dengan yodida ketika memasuki sel tiroid, karena keduanya memiliki volume molekul dan muatan yang sama. Tiosianat kemudian masuk ke dalam darah dan membentuk ion-ion goitrogen yang akan mengikat ion-ion yodium, akibatnya yodida yang akan digunakan untuk pembentukan hormon mono- (T1) dan diiodotironin (T2) sebagai prekursor hormon triiodotironin (T3) dan tiroksin (T4) berkurang, sehingga pembentukan hormon T3 dan T4 akan menurun. Kekurangan yodium ini menyebabkan kelenjar tiroid bekerja lebih keras untuk memenuhi kebutuhan hormon. Hal ini menyebabkan sel-sel membesar dan secara visual leher akan terlihat 


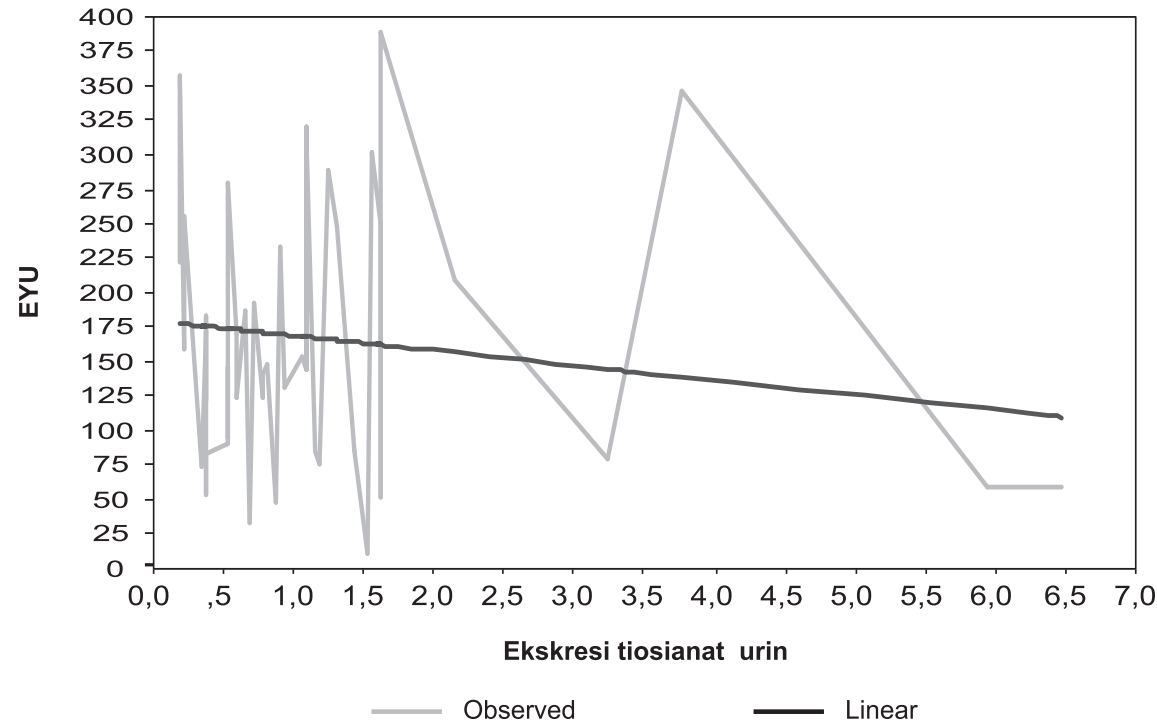

GAMBAR 4. Hubungan antara ekskresi tiosianat urin dengan kadar EYU

TABEL 12. Distribusi sampel berdasarkan status gangguan akibat kekurangan yodium (GAKY) dan asupan tiosianat

\begin{tabular}{|c|c|c|c|c|c|c|c|c|c|c|}
\hline \multirow{3}{*}{ Asupan tiosianat } & \multicolumn{4}{|c|}{ Status GAKY } & \multirow{2}{*}{\multicolumn{2}{|c|}{ Total }} & \multirow{3}{*}{$\chi^{2}$} & \multirow{3}{*}{$\mathbf{p}$} & \multirow{3}{*}{ OR } & \multirow{3}{*}{ IK $95 \%$} \\
\hline & \multicolumn{2}{|c|}{ GAKY } & \multicolumn{2}{|c|}{ Non-GAKY } & & & & & & \\
\hline & $\mathbf{n}$ & $\%$ & $\mathbf{n}$ & $\%$ & $\mathbf{n}$ & $\%$ & & & & \\
\hline Tinggi & 31 & 60,8 & 20 & 39,2 & 51 & 100 & 31,14 & $<0,001^{*}$ & 5,9 & $3,0-11,3$ \\
\hline Rendah & 41 & 20,9 & 155 & 79,1 & 196 & 100 & & & & \\
\hline Total & 72 & 29,1 & 175 & 70,9 & 247 & 100 & & & & \\
\hline
\end{tabular}

Keterangan:

* Bermakna $(p<0,05)$

membesar yang disebut dengan GAKY. Hal ini juga akan terlihat jelas bila seseorang kekurangan yodium.

Hasil ini diperkuat oleh penelitian Djayusmantoko (9) di Provinsi Jambi tahun 2004 yang melaporkan ada hubungan antara asupan tiosianat dengan kejadian GAKY. Subekti (23) yang melakukan penelitian di Kabupaten Banggai pada tahun 2001 juga membuktikan bahwa faktor risiko terjadinya gondok dipengaruhi oleh konsumsi makanan yang mengandung goitrogenik. Van der Laan (24) menemukan efek tiosianat yang dapat menghambat uptake yodium oleh kelenjar tiroid dan mempercepat pengeluaran yodida dari kelenjar tiroid. Jika kadar tiosianat darah melebihi $1 \mathrm{mg}$, maka akan terjadi hambatan pompa yodium (iodine pump) pada asupan yodium yang normal, sedangkan pada kadar tiosianat darah yang lebih tinggi lagi akan terjadi pula penghambatan pembentukan MIT, DIT, T3 dan T4.

Penelitian terhadap wanita usia subur, ibu hamil, ibu menyusui, dan anak sekolah di Kabupaten Banggai Sulawesi Tengah melaporkan timbulnya GAKY di daerah pantai disebabkan rendahnya yodium pada air minum, konsumsi umbi-umbian yang mengandung goitrogen, dan penggunaan garam yang tidak memenuhi standar kandungan yodium. Taha et al. (10) yang juga melakukan penelitian pada anak SD menyatakan asupan tiosianat hanya akan memperberat coastal goiter pada wilayah yang defisiensi yodium.

\section{KESIMPULAN DAN SARAN}

Pada penelitian ini tidak ditemukan adanya hubungan antara asupan yodium dengan GAKY berdasarkan palpasi, tetapi ada hubungan antara asupan yodium dengan GAKY berdasarkan kadar EYU. Antara asupan tiosianat dengan GAKY berdasarkan palpasi juga ditemukan hubungan yang bermakna, tetapi tidak ada hubungan antara asupan tiosianat dengan GAKY berdasarkan kadar EYU. Asupan yodium ditemukan paling tinggi pada daerah endemis berat dan skor FFQ yodium ditemukan lebih tinggi pada daerah endemis ringan. Asupan tiosianat dan skor FFQ tiosianat lebih tinggi pada daerah endemis berat daripada daerah endemis lainnya.

Berdasarkan hasil tersebut, disarankan kepada pemerintah Kabupaten Dairi agar dapat melakukan surveilan secara berkala yaitu pemeriksaan garam 2 kali/tahun, palpasi 1 kali/tahun, pemeriksaan EYU 1 kali/tahun, dan TSH neonatal setiap kelahiran. Selain itu juga perlu dilakukan KIE (komunikasi, informasi, edukasi) kepada anak sekolah dan masyarakat tentang pentingnya mengkonsumsi garam beryodium, penganekaragaman konsumsi pangan dan akibat GAKY bagi kualitas SDM (sumber daya manusia), serta pengurangan asupan bahan makanan yang mengandung tiosianat. 


\section{RUJUKAN}

1. Depertemen Kesehatan RI. Studi Evaluasi Proyek Intensifikasi Penanggulangan GAKY. Jakarta: Direktorat Bina Gizi Masyarakat; 2003.

2. Hetzel BS. SOS for A Billion The Nature and Magnitude of the lodine Deficiency Disorder. Delhi: Oxford University Press; 1996.

3. Linder MC. Biokimia Nutrisi dan Metabolisme. (Terjemahan) Parakkasi A. Jakarta: Penerbit UI Press; 1992.

4. Harahap $\mathrm{H}$. Masalah gizi mikro utama dan tumbuh kembang anak di Indonesia. Jakarta; 2002.

5. Setiadi E. Sifat Goitrogenik Singkong (Monihot utilissima). Cermin Dunia Kedokteran 1980;17:43-5.

6. Murdiana A. Penentuan Makanan yang Mengandung Goitrogenik Tiosianat sebagai Salah Satu Faktor Timbulnya GAKY. Bogor: Puslitbang Gizi Bogor; 2001.

7. Ali O. Peralihan Kesehatan Perkembangan dan Iktibar. Malaysia: Penerbit Universitas Kebangsaan Malasya; 1999.

8. Thilly $\mathrm{CH}$, Swennen B, Bourdoux P, Nambue K, Reyes RM, Gillies J, et al. The Epidemiology of lodine Deficiency Disorder in Relation to Goitrogenic Factors and Thyroid Stimulating Hormone Regulation. Am J Clin Nutr 1993;57:267S-70S.

9. Djayusmantoko. Konsumsi Zat Yodium dan Zat Goitrogenik sebagai Faktor Risiko GAKY padaAnak Sekolah Dasar di Kecamatan Tabir Ulu Kabupaten Merangin Provinsi Jambi [tesis]. Yogyakarta: Universitas Gadjah Mada; 2004.

10. Thaha AR, Dachlan DM, Jafar N. Analisis Faktor Risiko Coastal Goiter (Analysis of Risk Factor of Coastal Goiter). J. GAKY Indon 2002;1(1):9-17.

11. Santoso EB. Hubungan antara Konsumsi Makanan Goitrogenik dan Status Yodium pada Ibu Hamil Di Kecamatan Endemis GAKY Kabupaten Gunung Kidul di Yogyakarta [tesis]. Yogyakarta: Universitas Gadjah Mada; 2005.

12. Lemeshow S, Hosmer D, Klar J. 1990. Adequacy of Sample Size in Health Studies. (Terjemahan) Pramono D. Yogyakarta: UGM Press; 1997. h. 49-52.

13. WHO, Unicef, ICCIDD. Assesment of lodine Deficiency Disorders and Monitoring Their Elimination: A Guide for Programme Managers. Genewa: WHO, Unicef, ICCIDD; 2001.
14. Atmarita, Fallah TS. Analisis Situasi Gizi dan Kesehatan Masyarakat. Prosiding Widyakarya Nasional Pangan dan Gizi VIII. Jakarta: Direktorat Gizi Masyarakat Departemen Kesehatan RI; 2004.

15. Murdiana A, Saidin S. Kadar Sianida dalam Sayuran dan Umbi-Umbian di Daerah Gangguan Akibat Kurang Yodium (GAKY). Jakarta: Badan Litbang Kesehatan, Departemen Kesehatan dan Kesejahteraan Sosial; 2001.

16. Almatsier S. Prinsip Dasar IImu Gizi. Jakarta: PT Gramedia Pustaka Utama; 2001.

17. Rasmussen L, Ovesen L, Bulow I, Jorgensen T, Knudsen $\mathrm{N}$, Laurberg $\mathrm{P}$, et al. Relations between Various Measures of lodine Intake and Thyroid Volume, Thyroid Nodularity, and Serum Thyroglobulin. Am J Clin Nutr 2002;76(5):1069-76.

18. Dunn, John T. The Global Challenge of lodine Deficiency. In: Redaksi Jurnal GAKY Indonesia. Kumpulan Naskah Pertemuan IImiah Nasional Gangguan Akibat Kekurangan Yodium (GAKY) 2001. Jurnal GAKY Indonesia 2001;1(1):1-7.

19. Triyono, Gunanti IR. Identifikasi Faktor yang Diduga Berhubungan dengan Kejadian Gondok pada Anak Sekolah Dasar di Daerah Dataran Rendah. Jurnal GAKY Indonesia 2004;3:1-3.

20. Dahlberg PA, BergmarkA, Bjorck L, Bruce A, Hambraeus L, Claesson O. Intake of Thiocyanate by Way of Milk and Its Possible Effect on Thyroid Function. Am J Clin Nutr 1984;39: 416-20.

21. Saraswati E. Faktor-Faktor yang Berpengaruh terhadap Terjadinya GAKY di Kecamatan Pakis Jaya Kabupaten Karawang. Bogor: Puslitbang Gizi Bogor; 2000.

22. Sumby A. Hubungan Pola Konsumsi Pangan, Konsumsi Bahan Goitrogenik dan Penggunaan Garam Beryodium dengan Kejadian GAKY di Desa Wologai Tengah Kecamatan Detusoko Kabupaten Ende [tesis]. Surabaya: Universitas Airlangga; 2006.

23. Subekti I. Faktor-Faktor yang Berpengaruh terhadap Timbulnya GAKY di Daerah Pantai. Bogor: Puslitbang Gizi Bogor; 2001.

24. Van der Laan J, Van der Laan WP. Endocrinolog. In: Setiadi E, editor. Sifat Goitrogenik Singkong (Monihot utilissima). Cermin Dunia Kedokteran 1980;17:43-5. 